\title{
Research on Model and Mechanism of Autonomous Management for Cellular Manufacturing*
}

\author{
Qingshan Zhang, Xiang Li
}

School of Management, Shenyang University of Technology, Shenyang, China.

Email: zhangq1898@yahoo.com.cn; lixiang186@163.com

Receive December 22 ${ }^{\text {nd }}, 2011$; revised March $12^{\text {th }}, 2011$; accepted April $13^{\text {th }}, 2011$.

\begin{abstract}
International Engineering Consortium predicted that cellular manufacturing would become the main production model of manufacturing enterprises in the future. Based on elaborating the basic concepts, this paper proposes organizational forms, autonomous management models and coordination mechanism of cellular manufacturing, and takes expected return of two production cells as a coordination example, then gives coordination process and coordination strategy of cellular manufacturing, so as to expand production management theory and provide reference to cellular manufacturing enterprises.
\end{abstract}

Keywords: Cellular Manufacturing, Autonomous Management, Management Model, Coordination Mechanism

\section{Introduction}

Manufacturing enterprises in order to adapt to the fastchanging and unpredictable business environment, their organization forms began to change from traditional and hierarchical "the mechanical structural type" to flat and diverse "chemical molecule type" and "biological cell type”. Cellular manufacturing as the main transition representative, it can be less organizational level, parallel information flows and parallel decision-making systems organized to achieve agile and rapid response to the customer demands. Multi-species batch production enterprises take the cellular manufacturing have become a development trend. In recent years, foreign studies more focused on physical and technical factors of equipment layout and production processes [1-4], as well as the production organizational forms and technical support based on multi-enterprise co-production [5,6]. China's theoretical according to the status and existing problems in Chinese manufacturing, had done many researches on the construction of production cells and network production systems, production scheduling in the cases of single enterprise and multi-enterprise cooperation [7,8]. With required management way of cellular manufacturing trans-

\footnotetext{
*This research is sponsored by National Natural Science Foundation of China (70172042, 70472034) and Liaoning Key Research Base of Social and Science Federation. (2009LSLKtjyx-62).
}

forming from past centralized and stationary management method to distributed self-management and collaborative management, the research how to manage cellular manufacturing and which management models and optimum methods should be taken in the cases of a single enterprise and multi-enterprise cooperation is rare at present. This article attempts to comprehensively construct organizational forms of cellular manufacturing on basis of clarifying the concept of production cell, and then probes autonomous management model and coordination mechanism of cellular manufacturing, at last take expected return of two production cells as a coordination example, gives coordination process and coordination strategy of cellular manufacturing, to expand production management theory and provide support to manufacturing enterprises.

\section{The Concept and Organizational Forms of Cellular Manufacturing}

\subsection{The Concept of Cellular Manufacturing}

Cellular manufacturing originated in Europe, can be dated back to 1930s, it was to divide product components into different part families, and then distributed equipments according to group technology or typical technology process of part families, thus formed relatively closed 
physical device cells. In 1990s production cell had been successfully applied in Japanese electronics assembly industry. Production cell in this time was composed by ahandful of people, to independently complete a series of assignments, the most revolutionary is canceling convey belt in the job, which make site more flexible and easy to organize. With rapid development of modern information technology and growing popularity of global internet, many manufacturing enterprises both at home and abroad use advanced manufacturing technology and computer network connection, take production tasks as guidance to integrate useful resources and production courses, then form several parallel production cells for core business processes in single enterprise and multi-enterprise, thus achieve the enterprise production organization's flattening, modularization, information network, agility, integration and cooperation.

\subsection{The Organizational Forms of Cellular Manufacturing}

The organizational forms of cellular manufacturing are various; in accordance with different production situations of single enterprise and multi-enterprise, cellular manufacturing has the following forms:

1) Cellular manufacturing in single enterprise. It is mainly based on rules and requirements of technology process to arrange equipments, and then form relatively independent production cells, thus complete technical processes of part families. Usually organizational forms are Linear type, U type, S type, Loop type and Joint cells type, as shown in Figure 1, they are mainly suitable to enterprises with products of light weight and small volume, simple production processes and batch production.

2) Cellular manufacturing under multi-enterprise cooperation. It is to make a number of production cells among alliance enterprises constituting a no-wall, beyond the space constraints and connected by electronic means, multilayered, heterogeneous and network-based manufacturing system as shown in Figure 2. According to its reconfigurable, reusable, expandable dynamic characteristics, this form is mainly applicable to the following cooperation types of alliance enterprise as shown in Figure 3. First, a master multi-slave type, it is mainly applicable to complex products production. Second, peer-to-peer type, it applies to small companies, which have the know-how without large production facilities

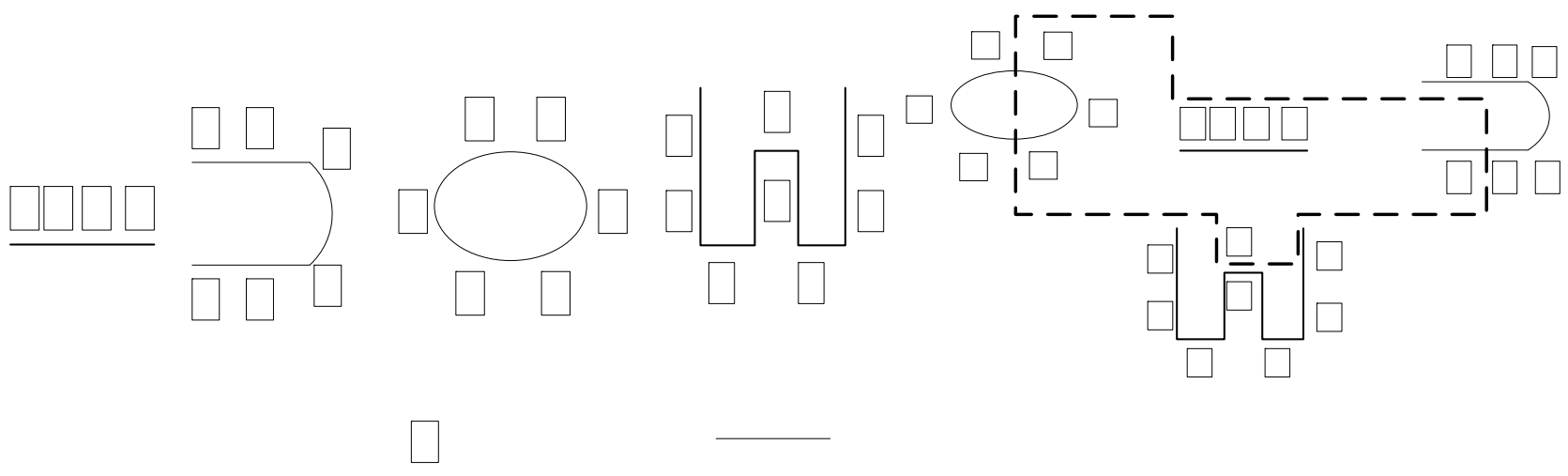

Figure 1. The organizational forms of cellular manufacturing in single enterprise.

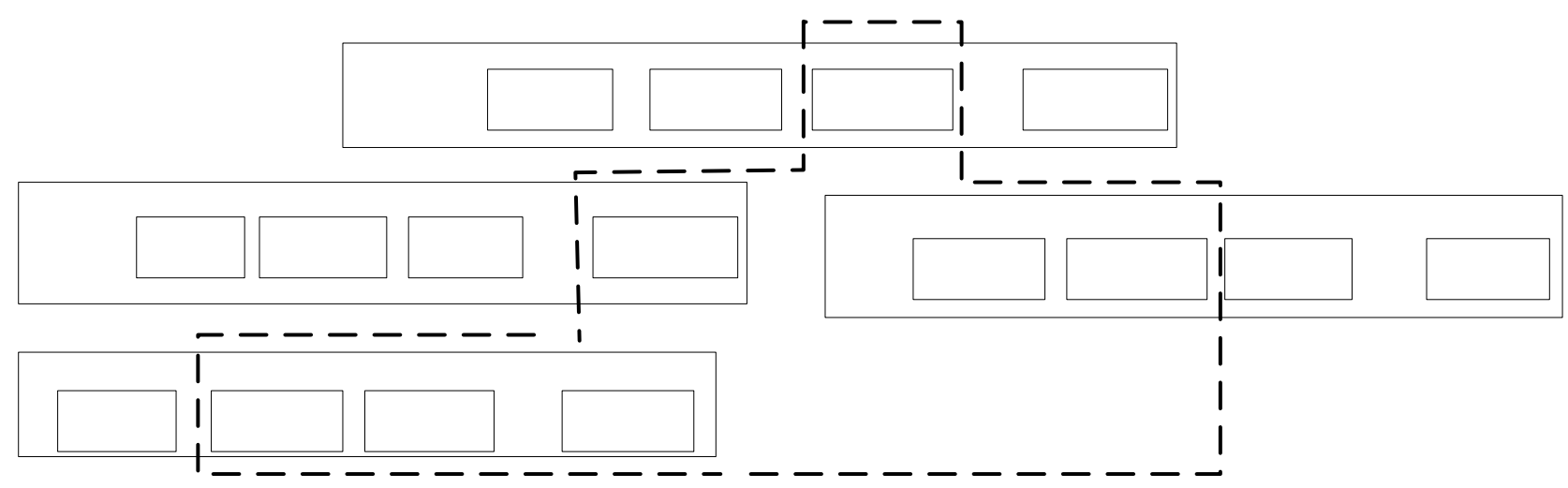

Figure 2. The organizational form of cellular manufacturing under multi-enterprise cooperation. 


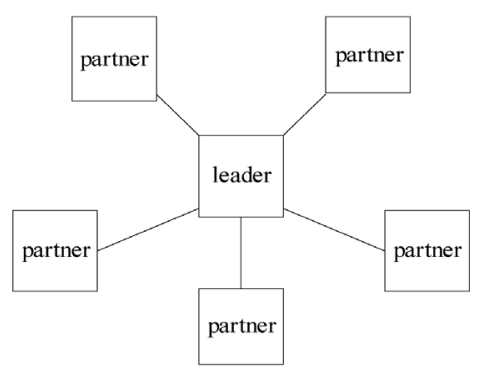

(a) a master multi-slave type

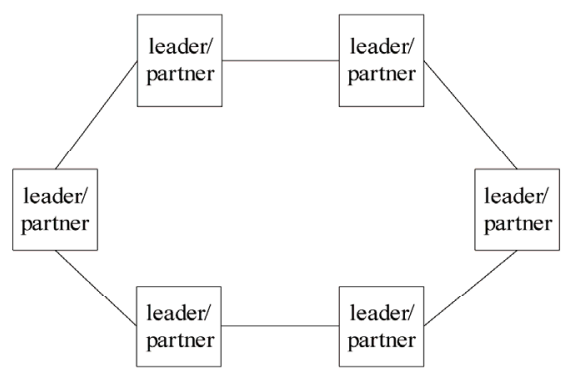

(b) peer-to-peer type

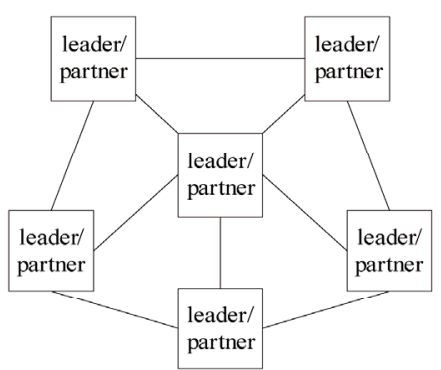

(c) network relation type

Figure 3. Enterprises alliance cooperation types.

and capabilities. Third, network relation type, it is suitable for large companies with affiliation, administrative, parent-subsidiary relationship and transnational corporation with contractual, principal-agent relationship.

\section{Autonomous Management Pattern of Cellular Manufacturing}

\subsection{Cellular Manufacturing Autonomous Management Pattern Model in Single Enterprise}

The basic idea of using autonomous management pattern of cellular manufacturing in single enterprise is: first, according to user order and market predictions enterprise generates product plans, thus builds production cells such as parts family division, equipment layout, staff arrangement and so on utilizing advanced cellular manufacturing technology and referring to product structure and compo-nents constitution table in the product planning. Then, based on material requirements planning and capacity planning derived from product plans, as well as combined load capacity of each production cell, enterprise works out master production planning, gives production task blocks and delivery deadlines to all production cells, and bestows some autonomy in decisionmaking and implementation on production cell. Finally, according to as-signed tasks and delivery dates production cells formulate detailed operational plan by their selves within given power purview, and carry out coordinative independent production scheduling and control. Meanwhile, through the computer software production cells dynamically feed back its production planning and implementation and completion of scheduling to the enterprise to carry out the global scheduling and control. Figure 4 shows an auto-nomous management pattern model framework diagram of cellular production in single enterprise.

\subsection{Cellular Manufacturing Autonomous Management Pattern Mode of Multi-Enterprise Collaboration}

Cellular manufacturing autonomous management pattern of Multi-enterprise collaboration is based on computer networks multi-agent co-production management model. The basic idea is: first, according to opportunity Products leader-enterprise or Alliance Management Committee carries out analysis of product capabilities and cost, outputs joint production decision and determines cooperative forms, then selects required production cells in cooperative enterprises. Second, according to judge result leader-enterprise or Alliance Management Committee preliminary gives production orders, then each production cell conducts operation planning according to the issued orders, the results of the planning in consultation and discussion form are submitted to leader-enterprise or Alliance Management Committee. Through repeated network consultation alliance enterprises finally accomplish the joint production planning of the entire project to achieve decomposition and distribution of productive tasks. Third, each production cell make issued production order disperses into executable processes plans, and then independently completes production scheduling and control functionality. At last, after the completion of the production tasks, leader-enterprise or Alliance Management Committee makes the performance evaluation to determine whether use or adjustment production cells of cooperative enterprises.

Combination of Figure 2, the article gives the cellular manufacturing Autonomous management pattern mode framework diagram of Multi-enterprise collaboration, as shown in Figure 5.

\section{Coordination Mechanisms of Autonomous Management of Cellular Manufacturing}

\subsection{Coordination Process Model}

After a single enterprise or multi-enterprise achieving production cells alliance, production cells cooperatively and competitively involve in production both cooperatively and competitively production activities. In production system of cellular manufacturing, all participants collect relevant data information primarily through the computer network, when find abnormal information, that 


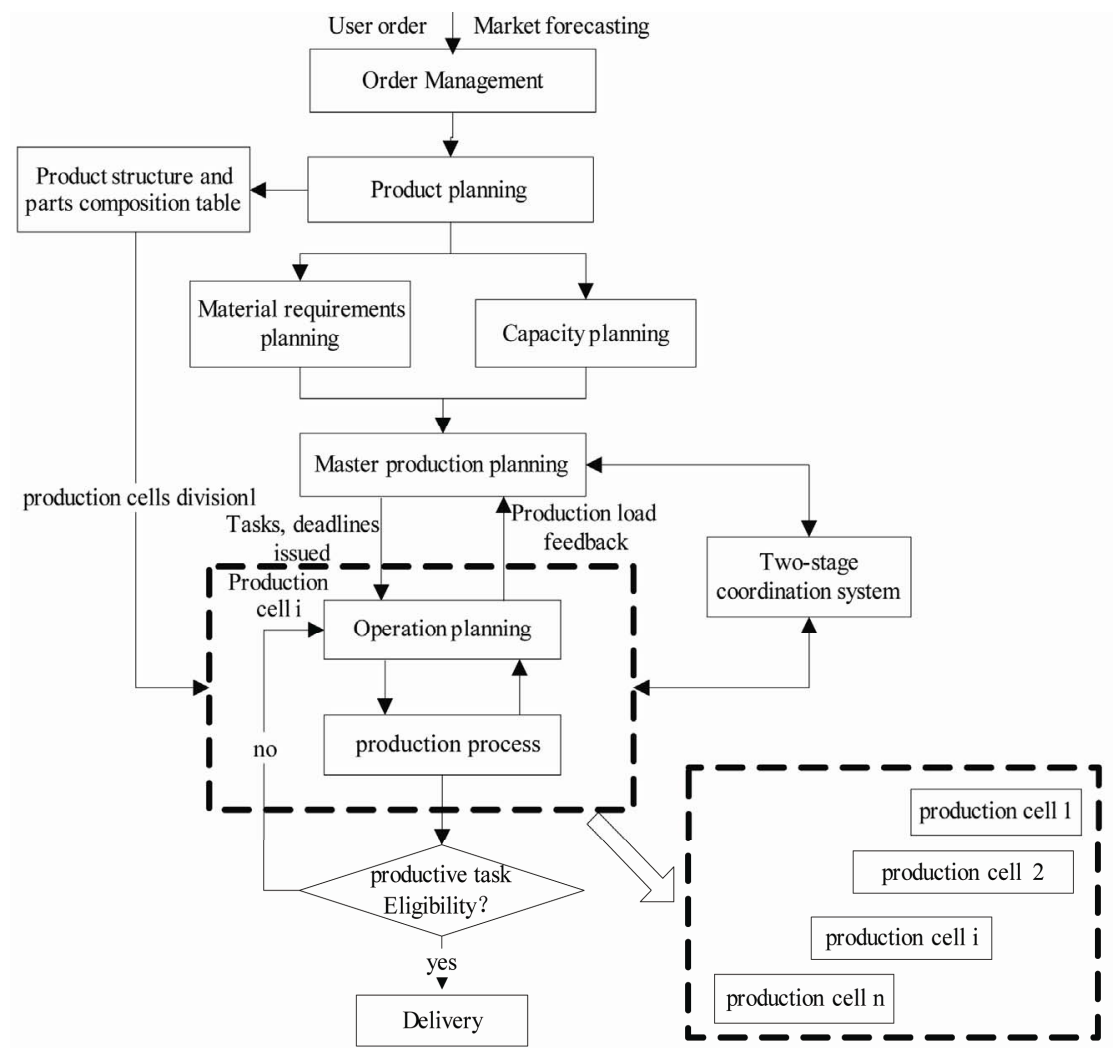

Figure 4. Autonomous management pattern model framework of cellular manufacturing in single enterprise.

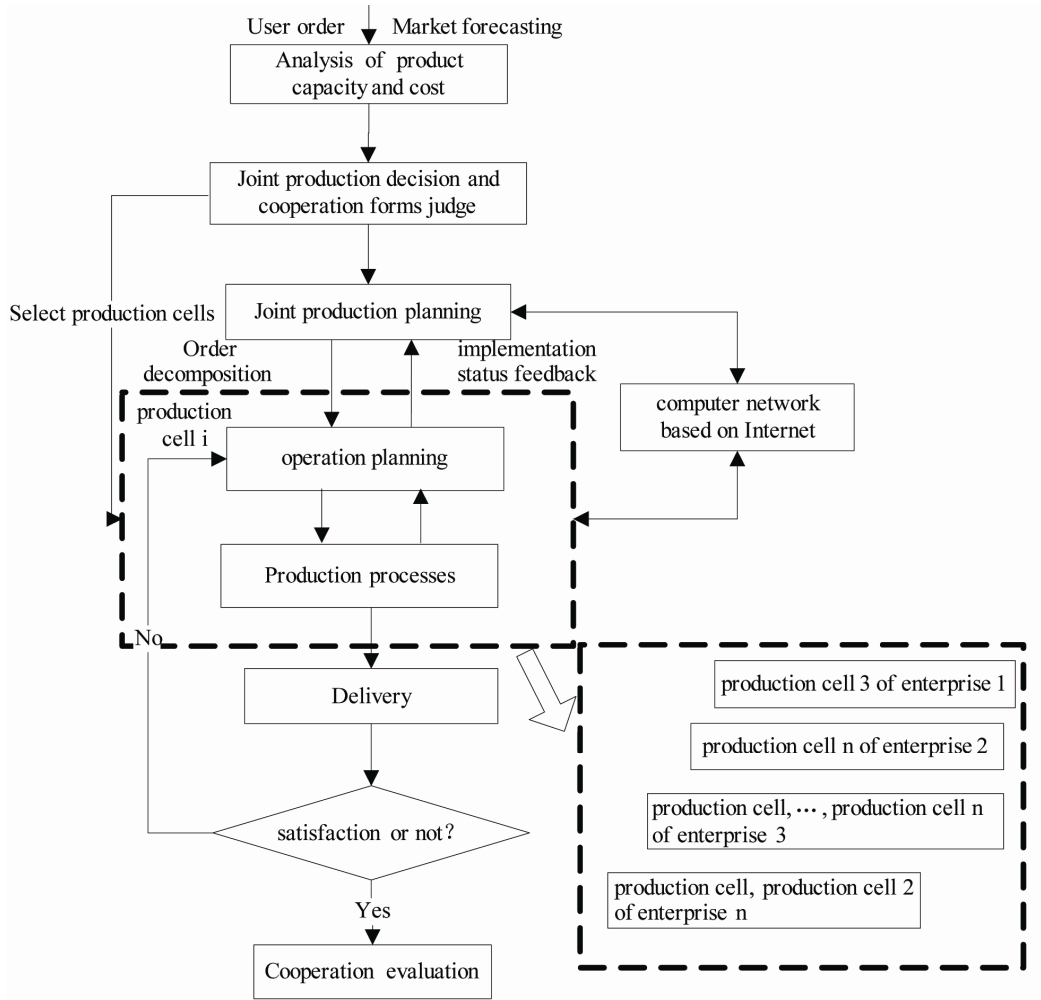

Figure 5. Cellular manufacturing autonomous management pattern model framework of multi-enterprises collaboration. 
is appearing contradictions or conflicts, in accordance with actual situation of main contradictions the involved production cells select cooperation strategies to promote the entire production system from time, space and function to achieve synergy re-state, when production opportunities for cooperation disappear, collaborative state will be damaged, that is the union of production cells disintegrated. If co-produced opportunities appear again, then enter a new round of production cells league, the formation of coordination mechanisms of cellular manufacturing as shown in Figure 6.

Coordination behavior model of autonomous management of cellular manufacturing can be described as:

$$
\mathrm{C}=(\mathrm{X}, \mathrm{Y}, \mathrm{F}, \mathrm{DGDS}, \mathrm{ARC})
$$

Among: X-contradictions set, Y-production cell coordination set, F-operational guidelines of production cells, DGDS-distributed group decision of production cells, ARC-accept region of production cells. Accept region is a range of target interval between expected and actual target, which can be accepted.

Take two production cells coordinating as case, set coordination production cells as $N_{1}$ and $N_{2}$, coordination conflicts is expected return, $p_{N_{1}}\left(x_{j}\right)$ and $p_{N_{2}}\left(x_{j}\right)$ are respectively expected turns of $N_{1}$ and $N_{2}$ for the $x_{j}$ question. Here takes concept of expected turn as judge concession criterion, its mathematical description as follows:

$$
r_{N_{1}}=\frac{p_{N_{1}}\left(x_{j}\right)}{p_{N_{1}}\left(x_{j}\right)+p_{N_{2}}\left(x_{j}\right)} ; \quad r_{N 2}=\frac{p_{N_{2}}\left(x_{j}\right)}{p_{N_{1}}\left(x_{j}\right)+p_{N_{2}}\left(x_{j}\right)}
$$

1) When $r_{N_{1}}>r_{N_{2}}, N_{1}$ should make concession, occurred gains $\Delta P_{1}\left(N_{1} \rightarrow N_{2}\right)$ which transferred to $N_{2}$.

2) When $r_{N_{1}}<r_{N_{2}}, N_{2}$ should make concession, occurred gains $\Delta P_{2}\left(N_{2} \rightarrow N_{1}\right)$ which transferred to $N_{1}$.

3) When $r_{N_{1}} \approx r_{N_{2}}$, the two sides have agreed on the expected return.

Expected return transfer occurred between coordination cells, as shown in Figure 7. In the premise of reaching common perception of expected return, involved coordination cells will conduct consultation and negotiation around the assured conflicts, as expected return. Then according to the accept region of involved production cells, they receive corresponding targets transfer to make consensus close to each others' accept regions, at last to mutually and friendly resolve conflicts, and then ensure production activities ongoing.

\subsection{Coordination Strategy}

1) Contract coordination strategy. Contract coordination strategy is decided by enterprise or multi-enterprise and production cells and is behavior strategy which specify and coordinate production cells in the form of commitment contract, The basic idea is first after reaching production cells alliance, through several rounds of consultations enterprise or multi-enterprise and production cells make a clear definition for their relations, and reach their specific commitments. Secondly, according to commitment contents to develop detailed rights range, and elaborate illustrate. Finally, make clear communication

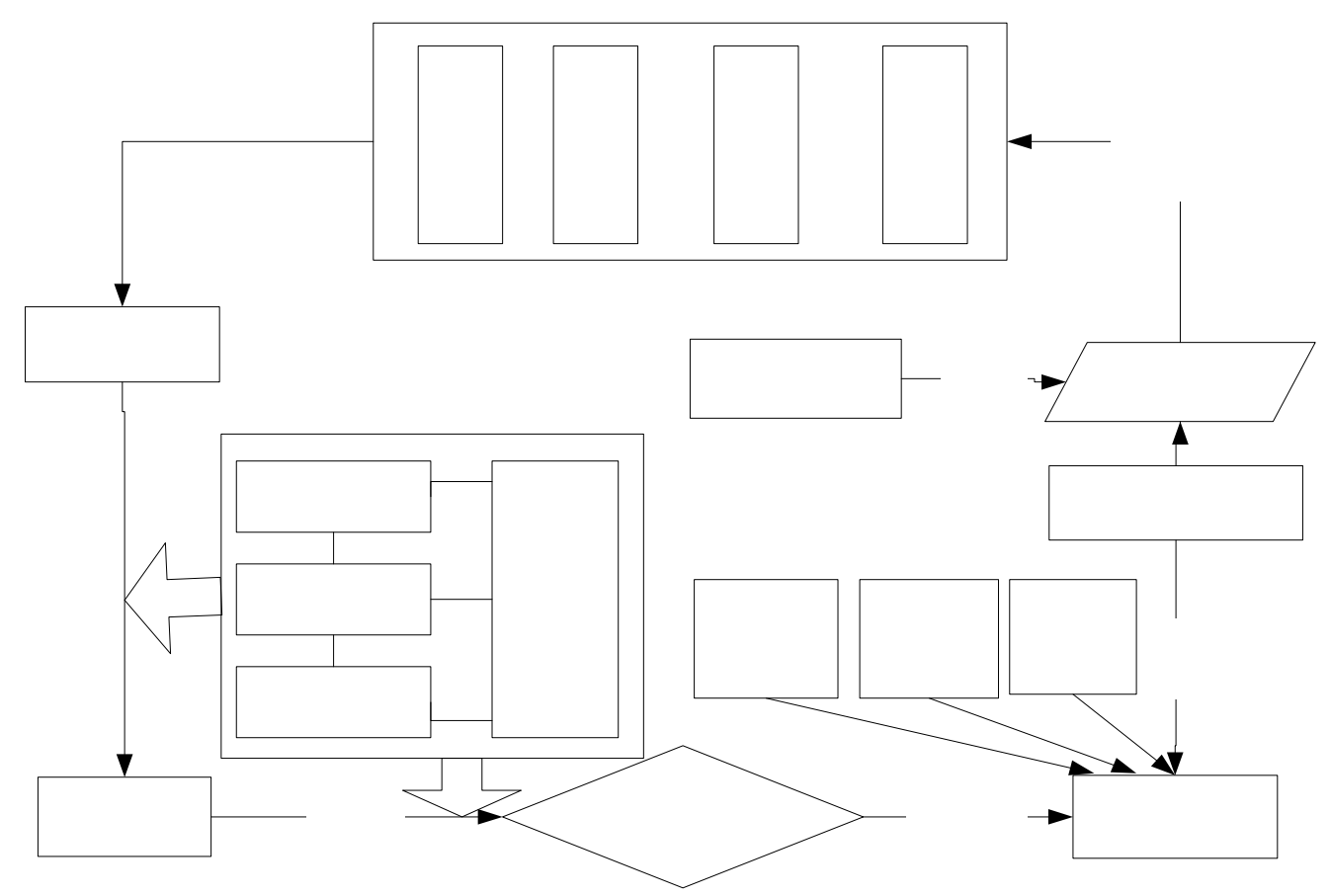

Figure 6. Formation model of coordination mechanism. 


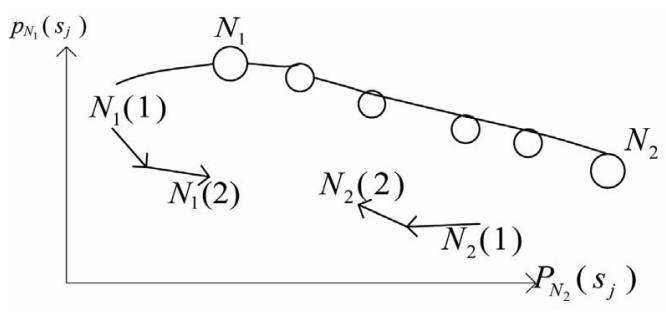

Figure 7. Benefits transfer diagram of the coordination cells.

channels and rights arrangements. Once contract coordinated strategies are formulated, all participators in cellular manufacturing should comply contract contents, then mutual supervision, to maintain production system of cellular manufacturing running well.

2) Communicative coordination strategy. As independence, autonomy and decentralization of cellular manufacturing, coordination between the production cells need to constantly communicate to promote information exchange and sharing, and the formation process of coordination mechanisms in cellular manufacturing need production cells reach a common cognitive model through communications and negotiations. The implementation of effective communication not only by the production management information system to strengthen relationship, interaction, and influence between production participators, but also requires all participators develop their cognitive framework through continuous learning, to promote achievement of mutually agreed intervals, and reduce confliction and contradiction generated, then ensure production activities orderly continued.

3) Credit coordination strategy. In cellular production, production cells are independent and equal, so multiagent coordination is bound to take some trust risks, if not established credit system between production cells, production energy of production cells will virtually be the production will be dispersed, therefore, before reaching a alliance of production cells, also need to establish a credit system, which is used to evaluate credit of production cells during actual production process, and then improved credit system according to evaluation results, to strictly filter involved qualification of next round of production cells. By the end of building and improve credit system, all participators of cellular manufacturing can be able to consciously and actively fulfill their obligations, and gradually form coexistence, free and win-win synergy relationship without supervision, which not only reduces coordination cost and improve production efficiency, but also cultivate a good corporate culture $[9,10]$.

\section{Conclusions}

Cellular manufacturing has become a development trend of organizational transformation of current manufacturing enterprises. The organizational forms of cellular manufacturing are given by this paper have synthesized organizational forms of cellular manufacturing of single enterprise and multi-enterprise, moreover, autonomous management model and coordination mechanism are proposed by this paper overcome the stereotype that cellular manufacturing puts emphasis on hardware research such as cell formation, equipment layout, production scheduling, etc., and get rid of focused and fixed management pattern in the past. These conform to the development direction of distributed self-management and collaborative management based on modern production, not only to expand and enrich production management theory, but also to provide reference to the specific organization and management practices of cellular manufacturing enterprises.

\section{REFERENCES}

[1] N. Hyer and K. Brown, "California Management Review," Work Cells with Staying Power: Lessons for Process-Complete Operation, Vol. 46, No. 1, 2003, pp. 27-52.

[2] M. Kizil and T. C. Papadopoulou, "Evaluation of Dispatching Rules for Cellular Manufacturing,” International Journal Advanced Manufacturing Technology, Vol. 7, 2005, pp. 45-48.

[3] L. Quarterman, "How to Balance a Manufacturing Work Cell,” Institute of Industrial Engineers-IE Solutions, Cleveland Ohio, 2000.

[4] M. Dawande, H. N. Geismar, S. P. Sethi and C. Sriskandarajah, "Sequencing and Scheduling in Robotic Cells: Recent Developments," Journal of Scheduling, Vol. 8, No. 5, 2005, pp. 387-342. doi:10.1007/s10951-005-2861-9

[5] K.-C. Ko and P. J. Egbelu, "Virtual Cell Formation," International Journal of Production Research, Vol. 41, No. 11, 2003, pp. 2365-2389.

doi:10.1080/0020754031000087193

[6] J. Slomp, B. V. Chowdary and N. C. Suresh, "Design of Virtual Manufacturing Cells: A Mathematical Programming Approach," Robotics and Computer-Integrated Manufacturing, Vol. 21, No. 3, 2005, pp. 273-288. doi:10.1016/j.rcim.2004.11.001

[7] S. Zhang, "Autonomous Manufacturing lsland: A New Continuous lmprovement Concept,” Journal of Tongji University, Vol. 25, No. 6, 1997, pp. 687-692.

[8] S. Zhang and D.-S. Lin, "The Disperse Networked Manufacturing: A Sustainable Developing Production Mode,” Chinese Mechanical Engineering, Vol. 9, No. 2, 1998, pp. 68-70.

[9] L. P. Khoo and M. Y. Loi, “A Tabu-Enhanced Genetic Algorithm Approach to Agile Manufacturing," International Journal Advanced Manufacturing Technology, Vol. 20, No. 9, 2002, pp. 692-700. doi:10.1007/s001700200208 
[10] Q. S. Zhang, “The Research on Intergrated Production Planning and Controlling Method of Customer-Centered Production,” Journal of Industrial Engineering and En- gineering Management, Vol. 22, No. 1, 2008, pp. 151153. 